\title{
MODEL INSTRUMEN PENILAIAN KINERJA GURU BIMBINGAN KONSELING BERBASIS BIMBINGAN KONSELING KOMPREHENSIF
}

\author{
Slamat Fitriyadi dan Iip Istirahayu \\ Sekolah Tinggi Keguruan Ilmu Pendidikan (STKIP Singkawang) \\ e-mail: ahmadfitriyadi521@gmail.com
}

\begin{abstract}
Abstrak: Guru bimbingan dan konseling merupakan bagian dari sistem pendidikan yang ada di sekolah menengah pertama maupun atas. Program BK yang dilaksanakan sekolah harus lebih komprehensif dengan tujuan dapat menjangkau seluruh peserta didik dan lingkungan peserta didik. Atas dasar itu maka kinerja guru BK harus dinilai, untuk menilai kinerja guru BK diperlukan instrumen penilaian kinerja guru BK berdasarkan program BK Komprehensif yang telah dibuat. Tujuan penelitian ini adalah: (1) menggambarkan instrumen penilaian kinerja guru BK faktual, (2) menghasilkan model instrumen penilaian kinerja guru BK yang Komprehensif, (3) menilai kelayakan model instrumen penilaian kinerja guru BK berbasis BK Komprehensif. Penelitian ini menggunakan pendekatan Research and Development (R\&D) dengan tahap: (1) studi pendahuluan, dilakukan terhadap guru BK, Koordinator BK, kepala sekolah, Pengawas SMAN Kota Magelang, (2) pengembangan model IPKGBK berbasis BK Komprehensif melibatkan para pakar dan praktisi yang terdiri dari 2 validator ahli bidang manajemen BK dan validator praktisi yang terdiri dari koordinator BK dan Guru BK di SMA Negeri 1 dan 2 Kota Magelang, (3) kelayakan model instrumen penilaian kinerja guru BK berbasis BK Komprehensif. Teknik pengumpulan data menggunakan wawancara, diskusi, dan pengamatan dokumen faktual. Analisis data dilakukan dengan analisis isi. Hasil studi pendahuluan menunjukkan adanya ketidaksesuaian antara IPKGBK Faktual dengan program bimbingan konseling komprehensif yang dibuat dan dilaksanakan di SMA Negeri 1 dan 2 Kota Magelang. Hal ini terlihat dari komponen isi item pernyataan dari perencanaan, pelaksanaan, evaluasi, dan tindak lanjut yang belum menggambarkan secara jelas penilaian kinerja guru BK yang telah melaksanakan program BK Komprehensif. Hasil pengembangan menunjukkan IPKGBK pengembangan layak dan sesuai dengan pelaksanaan program BK komprehensif yang telah dilaksanakan di SMA Negeri 1 dan 2 Kota Magelang. Kepala Sekolah atau Koordinator BK perlu menggunakan instrumen penilaian kinerja guru BK berbasis BK Komprehensif untuk menilai kinerja guru BK yang sudah menerapkan program BK Komprehensif, dan Badan Pengembangan SDM Pendidikan dan Penjamin Mutu Pendidikan dalam buku kerja pengawas sekolah, serta menyeragamkan bentuk IPKGBK Komprehensif untuk sekolah-sekolah yang telah melaksanakan program BK Komprehensif.
\end{abstract}

Kata kunci: Instrumen, Penilaian, Kinerja guru BK, BK komprehensif.

Abstract: Guidance and Counseling teacher became a part of education system eithers in Junior or Senior high schools. Guidance and Counseling program which in held in a school should be more comprehensive with the purpose to reach out all of the students and their environment. Based on that situation, Guidance and Counseling teachers' performance should be evaluated. The objectives of this study are: (1) Describe the instrument of factual Guidance and Counseling teachers' performance, (2) Product a comprehensive instrument model for evaluating a Guidance and Counseling teachers' performance, (3) Evaluate the appropriateness of instrument model to evaluate teacher's performance based on comprehensive Guidance and Counseling. This study uses a research and development approach. The steps are: (1) Preminary study has done to the Guidance and Counseling teacher's Guidance and Counseling coordinators, the principles, and supervisor of senior high school of Magelang City. (2) Developing a model of IPKGBK based on comprehensive Guidance and Counseling that involve some experts and practitioners that consists of two validator experts on Guidance and Counseling management and validator of practitioners. They are Guidance and Counseling coordinator and Guidance and Counseling teacher in senior high school one and two of Magelang City.(3) The appropriateness model of instrument for evaluating the Guidance and Coun- 
seling teacher's performance based on comprehensive Guidance and Counseling. The data collection uses interview technique, discussion, and research to the factual document. Analysis of the has been done by analyzing of the content. The result of the preliminary study shows that there is inappropriate between factual IPKGBK and comprehensive Guidance and Counseling program. This is shown from the component content in the item of the statement of plan, execution, evaluation, and follow-up that hasn't show the evaluation of the Guidance and Counseling teacher's performance clearly. The Development result shows IPKGBK is suitable and appropriate with the implementation of comprehensive Guidance and Counseling program that has been used in state high schools one and two of Magelang City. The Principle or Guidance and Counseling coordinator need to use the instrument of teacher's performance evaluation based on comprehensive Guidance and Counseling teacher's performance. It also can be used ad reference source of development for education development and education quality on the workbook of school supervisor and harmonization of Comprehensive IPKGBK form for schools that have implemented the Comprehensive guidance and counseling program.

Keywords: instrument, evaluation, performance guidance and counseling teacher, guidance and counseling comprehensive

\section{PENDAHULUAN}

Pelaksanaan tugas untuk guru bimbingan dan konseling/konselor diamanatkan di dalam peraturan Menteri Pendidikan Nasional Nomor 27 Tahun 2008 tentang Standar Kualifikasi Akademik dan Kompetensi Konselor (SKAKK) pada penguasaan kompetensi pedagogik, kepribadian, sosial dan profesional. Sistem penilaian kinerja guru BK/konselor adalah sebuah sistem penilaian kinerja berbasis bukti (evidence-based appraisal) yang didesain untuk mengevaluasi tingkatan kinerja guru BK/konselor secara individu dalam melaksanakan tugas utamanya sebagai guru profesional.

Penilaian kinerja diharapkan berimplikasi positif terhadap perbaikan dan peningkatan profesionalisme guru BK/konselor, juga harus berdampak pada peningkatan prestasi peserta didik. Sistem ini merupakan bentuk penilaian yang sangat penting untuk mengukur kinerja guru $\mathrm{BK} /$ konselor dalam melaksanakan pekerjaannya sebagai bentuk akuntabilitas sekolah. Dalam konteks Peraturan Menteri Negara Pendayagunaan Aparatur Negara dan Reformasi Birokrasi Nomor 16 Tahun 2009 tentang petunjuk teknis jabatan fungsional guru dan angka kreditnya. Penilaian kinerja guru memiliki dua fungsi utama, yaitu untuk: (1) menilai unjuk kerja guru baik guru mapel dan guru BK/Konselor di dalam menerapkan semua kompetensi yang terwujudkan dalam pelaksanaan tugas utamanya pada proses pembelajaran, pembimbingan, atau pelaksanaan tugas tambahan yang relevan dengan fungsi sekolah/madrasah.

Dengan demikian, hasil penilaian kinerja menjadi profil kinerja guru yang dapat memberikan gambaran kekuatan dan kelemahan guru; (2) menghitung angka kredit yang diperoleh guru atas kinerja pembelajaran, pembimbingan, atau pelaksanaan tugas tambahan yang relevan dengan fungsi sekolah/madrasah pada tahun penilaian kinerja guru dilaksanakan. Kegiatan tersebut dilakukan setiap tahun sebagai bagian dari proses pengembangan karier dan promosi guru untuk kenaikan pangkat dan jabatan fungsionalnya.

Bimbingan dan Konseling komprehensif memakai titik pandang (teori) perkembangan dengan alasan BK tidak hanya berurusan dengan perilaku mal-adaptif dan mencegah perilaku maladaptif tersebut, tetapi untuk pengembangan 
perilaku efektif. Pendekatan dalam bimbingan dan konseling menuntut bimbingan dan konseling memberikan layanan secara proaktif melebihi pendekatan krisis, remedial, dan preventif (Kartadinata, 2003). Sehubungan dengan sifat program bimbingan dan konseling komprehensif, ada tiga hal yang secara mendasar perlu diperhatikan dalam penyusunan program bimbingan dan konseling di sekolah, yaitu: (1) ruang lingkup yang menyeluruh, (2) dirancang lebih berorientasi pencegahan dan, (3) tujuannya pengembangan potensi siswa. (Suherman, 2013).

Sehubungan dengan itu maka penilaian kinerja guru BK yang ada di sekolah yang sudah menerapkan program BK Komprehensif harus sesuai juga dengan instrumen penilaian kinerja guru BK yang akan digunakan untuk menilai kinerja guru BK tersebut. Wirawan (2009:76) menyatakan pada prinsipnya isi instrumen penilaian kinerja adalah: (a) nama organisasi, (b) identifikasi karyawan: nama, unit kerja, jabatan, pangkat. (c) Identifikasi penilai: nama, jabatan, unit kerja, (d) masa periode penilaian, (e) butir-butir indikator kinerja, (f) deskriptor level kinerja, (g) catatan pribadi, (h) tanggapan penilai atas penilaian, dan (i) tanda tangan penilaian atas ternilai. Pride et al. (2006:5) menyatakan bahwa dasar sistem penilaian kinerja guru adalah menggunakan tugas dan tanggung jawab guru yang digambarkan secara jelas. Tugas dan tanggung jawab yang diharapkan untuk kinerja guru didefinisikan dengan menggunakan tingkatan: (a) domain, (b) tanggung jawab, dan (c) indikator kinerja.

Berdasarkan hasil pengisian angket dan wawancara yang dilakukan oleh peneliti kepada kepala sekolah SMA 2 Kota Magelang tanggal 28 Desember 2013 yang menyatakan belum adanya format khusus tentang instrumen yang dapat digunakan untuk menilai kinerja guru BK di dalam melaksanakan tugasnya, dan sumber lain dari beberapa koordinator BK di beberapa Sekolah Menengah Atas Negeri di Kota Magelang menunjukkan bahwa sebenarnya instrumen penilaian kinerja guru BK faktual yang digunakan selama ini sudah ada dan digunakan untuk menilai kinerja guru BK di seluruh SMAN di Kota Magelang.

Hal ini tentunya menjadi tidak efektif apabila dilihat dari komponen-komponen dan indikator-indikator kinerja yang ada di dalam instrumen model faktual yang selama ini digunakan masih mengacu kepada indikator dan komponen penilaian kinerja guru yang melaksanakan program BK 17 di sekolahnya sedangkan untuk sekolah yang sudah melaksanakan program BK Komprehensif juga masih menggunakan model instrumen penilaian kinerja yang sama di dalam menilai kinerja guru BK. Berangkat dari hal itulah maka diperlukannya sebuah instrumen penilaian kinerja guru yang tepat sesuai dengan program Bimbingan dan Konseling yang sudah diterapkan oleh guru bimbingan konseling yang ada di kedua SMA Negeri tersebut.

\section{METODE PENELITIAN}

Jenis penelitian ini merupakan jenis penelitian dan pengembangan. Seringkali penelitian ini disebut dengan research and development (R\&D). Penelitian dan pengembangan merupakan metode penelitian yang digunakan untuk menghasilkan produk tertentu dan menguji efektivitas produk tersebut (Sugiyono, 2009:407). Model pengembangan dalam penelitian ini merupakan model konseptual, di mana model instrumen penilaian kinerja guru bimbingan dan konseling berbasis BK komprehensif yang dihasilkan merupakan analisis komponen-komponen yang harus ada di dalam instrumen penilaian kinerja guru BK/konselor berbasis Bimbingan dan Konseling komprehensif. 
Model instrumen penilaian kinerja guru bimbingan dan konseling berbasis BK komprehensif yang dikembangkan mengadaptasi pada model IPKGBK faktual. IPKGBK faktual menggunakan model skala bertingkat. Pengadopsian ini dilakukan dengan alasan: (1) model rating scale dapat menunjukkan derajat sensitivitas indikator penilaian; (2) tugas guru BK melakukan perencanaan dan melaksanakan pembimbingan, mengevaluasi dan menilai hasil bimbingan, menganalisis hasil evaluasi pembimbingan, dan melaksanakan tindak lanjut pembimbingan.

Dalam penelitian ini, penelitian dan pengembangan digunakan untuk mengembangkan model. Kesepuluh langkah yang dikemukakan Borg \& Gall (2003) oleh Samsudi dikelompokkan menjadi dua langkah utama (Samsudi, 2009:92) yaitu: Pertama, tahap survei yang mencakup: (1) studi literatur, (2) studi pengumpulan data lapangan berkaitan dengan permasalahan yang akan dipecahkan, (3) dan deskripsi hasil temuan lapangan. Kedua, tahap pengembangan dan hasil mencakup langkah-langkah sebagai berikut: (1) merumuskan format desain produk, (2) mengembangkan rumusan awal (desain) produk yang akan dikembangkan, (3) validasi (expert judgment), (4) evaluasi dan perbaikan dalam rangka finalisasi produk akhir, (5) melakukan uji coba lapangan yang bersifat luas, (6) melakukan evaluasi dan penyempurnaan dalam rangka finalisasi produk akhir, (7) hasil produk akhir.

Instrumen pengumpulan data dalam penelitian ini menggunakan panduan wawancara dan dokumentasi (berupa catatan substansi dan penggunaan model Instrumen Penilaian Kinerja Guru BK faktual. Data pengukuran kebutuhan, pendapat, dan masukan untuk IPKGBK pengembangan berbasis BK komprehensif dari subjek uji kelayakan model diperoleh dengan pedoman diskusi saat kegiatan FGD dilaksanakan, Data evaluasi kelayakan model IPKGBK pengembang- an berbasis BK komprehensif diperoleh melalui pedoman diskusi di saat kegiatan FGD dilaksanakan untuk melihat tingkat kelayakan model pengembangan.

\section{HASIL DAN PEMBAHASAN}

Hasil penelitian menunjukkan bahwa peneliti menemukan adanya perbedaan instrumen penilaian kinerja guru BK/Konselor yang selama ini digunakan untuk menilai kinerja guru BK/ Konselor. Untuk IPKGBK II yang diperoleh dari koordinator BK SMA Negeri 2 Kota Magelang merupakan instrumen penilaian kinerja guru BK yang isinya sudah memasukkan komponenkomponen BK Komprehensif hanya saja belum terlalu terperinci/mendalam menggali kinerja guru BK/Konselor yang sudah menerapkan BK Komprehensif, walaupun dalam penggunaannya lebih memudahkan penilai dalam mengukur tingkat kinerja guru BK/Konselor. Instrumen IPKGBK II yang digunakan saat ini juga menurut peneliti lebih cenderung untuk menilai penguasaan kompetensi guru BK yang tertuang di dalam permendiknas No.27 Tahun 2008 tentang standar kualifikasi akademik dan kompetensi konselor, bukan kinerja.

Sedangkan IPKGBK 1 diperoleh dari Koordinator BK SMA Negeri 1 Kota Magelang merupakan instrumen penilaian kinerja guru BK yang isinya belum mencantumkan secara jelas hal-hal yang termuat di dalam BK Komprehensif seperti: (1) indikator-indikator komponen instrumen, (2) item pernyataan penilaian kinerja guru BK Komprehensif. Instrumen IPKGBK 1 faktual juga belum mempunyai ketentuan dan ketegasan yang jelas di dalam menilai kelengkapan dokumen yang diperlukan guru BK/Konselor untuk menentukan skala penilaian di dalam instrumen tersebut. Dampak dari penerapan model-model instrumen IPKGBK faktual ini mengakibatkan 
belum adanya standar penilaian yang sama di antara para sekolah menengah negeri yang telah mengaplikasikan BK Komprehensif.

Instrumen penilaian kinerja guru bimbingan dan konseling (IPKGBK) yang telah divalidasi oleh ahli dan praktisi mencakup tiga, yaitu: (1) pendahuluan berisi (rasional dan konten), (2) isi instrumen, (3) petunjuk pelaksanaan model instrumen pengembangan. Model instrumen penilaian kinerja guru BK final yang telah divalidasi oleh validator ahli yang berjumlah 4 orang meliputi: 2 validator pembimbing dan 2 validator di luar pembimbing yang berkompeten dalam memberikan masukan, saran terkait model pengembangan instrumen penilaian kinerja guru BK berbasis BK Komprehensif dan validator praktisi yang berjumlah 7 orang guru BK dari SMA Negeri 1 dan SMA Negeri 2 Kota Magelang yang diselenggarakan melalui From Group Discussion (FGD) untuk meminta masukan, saran, serta pendapat dari model pengembangan serta menilai kelayakan dari model pengembangan yang telah dibuat.

Instrumen Penilaian Kinerja Guru BK/Konselor berbasis BK (IPKGBK) pengembangan layak digunakan menilai kinerja guru BK yang sudah melaksanakan program BK Komprehensif di sekolahnya. Kinerja guru BK merupakan unjuk kerja dari kompetensi yang harus dikuasai oleh guru BK. Kompetensi diartikan sebagai seperangkat tindakan cerdas dan penuh tanggung jawab yang dimiliki seseorang sebagai syarat untuk dianggap mampu oleh masyarakat dalam melaksanakan tugas-tugas sesuai dengan pekerjaan tertentu. (KepMenDikNas No.045/U/2002). Seorang guru BK/Konselor dituntut untuk menguasai empat kompetensi yang terdiri dari kompetensi pedagogik, kepribadian, sosial, dan profesional (Permendiknas No.27 Tahun 2008 tentang standar kualifikasi akademik dan kompetensi konselor).
Instrumen Penilaian Kinerja Guru BK/ Konselor (IPKGBK) pengembangan ini memiliki validitas internal dan eksternal. Memiliki validitas internal, karena instrumen ini mencerminkan yang seharusnya diukur, dibangun dari teori pendukung yang terkait dengan kinerja guru BK yang sudah melaksanakan program BK Komprehensif serta memiliki validitas eksternal karena dibuat sesuai dengan fakta yang ada di lapangan, dan mendasarkan kepada kebutuhan guru BK/ Konselor. Instrumen yang mempunyai validitas eksternal bila kriteria di dalam instrumen disusun berdasarkan fakta-fakta empiris.

Instrumen Penilaian Kinerja Guru BK/Konselor (IPKGBK) pengembangan memiliki kemudahan di dalam penggunaan dikarenakan dalam deskripsi item instrumen penilaian disediakan skala penilaian rentang 1 (apabila tidak ada dokumen, 2 (apabila dokumen tidak lengkap), 3 (apabila dokumen lengkap) yang disesuaikan dengan bukti fisik (dokumen) yang ditentukan untuk menentukan nilai yang diperoleh oleh guru BK/Konselor. Menurut Sugiyono (2009: 173) Instrumen penilaian yang reliabel adalah instrumen yang bila digunakan beberapa kali untuk mengukur objek yang sama akan menghasilkan data yang sama.

Instrumen penilaian kinerja guru BK/Konselor (IPKGBK) pengembangan memiliki kepraktisan di dalam menentukan nilai hasil pernyataan instrumen penilaian kinerja guru BK menggunakan program Microsoft excel dan mampu menghitung secara otomatis total nilai kinerja guru BK yang didapatkan sebagai acuan dalam menentukan skor syarat minimal yang diperoleh oleh guru BK di dalam menentukan kenaikan pangkat/jenjang karier guru BK yang bersangkutan.

Komponen-komponen indikator kinerja guru BK mulai dari perencanaan, pelaksanaan, evaluasi dan tindak lanjut yang ada dalam instrumen penilaian kinerja guru BK/Konselor pe- 
ngembangan mengacu kepada teori-teori yang ada di dalam BK Komprehensif. Di dalam BK Komprehensif pelayanan tersebut dikemas dalam empat komponen yaitu: (1) Kurikulum bimbingan, (2) Perencanaan individual, (3) Pelayanan responsif (4) Dukungan sistem (Gybers dan Henderson, 2006:139-140). Keempat komponen tersebut dijabarkan kembali ke dalam berbagai strategi-strategi yang ada di dalam setiap komponen program BK komprehensif.

\section{KESIMPULAN}

Instrumen Penilaian Kinerja Guru BK/Konselor (IPKGBK) faktual terdiri dari instrumen 1 dan II. Instrumen penilaian kinerja guru BK faktual 1 merupakan instrumen penilaian kinerja guru BK yang belum mencantumkan indikatorindikator komponen yang tertuang di pernyataan penilaian kinerja guru BK dalam mengaplikasikan komponen-komponen BK Komprehensif. Instrumen IPKGBK faktual juga belum mempunyai ketentuan yang jelas untuk menilai kelengkapan dokumen yang diperlukan guru BK/konselor dalam menentukan skala penilaian instrumen tersebut. Sedangkan instrumen penilaian kinerja guru BK faktual II merupakan instrumen penilaian kinerja guru BK yang isinya sudah memasukkan sedikit komponen-komponen BK Komprehensif hanya saja belum terlalu terperinci walaupun dalam penggunaannya memudahkan penilai untuk menggunakannya dan lebih IPKGBK II cenderung lebih cocok untuk menilai penguasaan kompetensi guru BK yang tertuang di dalam permendiknas No.27 Tahun 2008 tentang standar kualifikasi akademik dan kompetensi konselor. Sehingga dapat disimpulkan bahwa IPKGBK 1 dan II belum memenuhi syarat di dalam menilai kinerja guru BK di dalam mengaplikasikan komponen-komponen yang ada dalam BK Komprehensif.
Instrumen penilaian kinerja guru BK/Konselor (IPKGBK) hipotetis dibuat berdasarkan hasil analisis instrumen penilaian kinerja guru BK faktual 1 dan II serta pengukuran kebutuhan instrumen penilaian kinerja guru BK. IPKGBK hipotetis lebih sesuai dengan karakteristik kerja guru BK/Konselor yang sudah menerapkan program BK Komprehensif

Instrumen penilaian kinerja guru BK/Konselor (IPKGBK) pengembangan merupakan hasil dari instrumen penilaian kinerja guru BK hipotetis yang telah divalidasi oleh ahli bimbingan dan konseling dan praktisi bidang bimbingan dan konseling. Instrumen penilaian kinerja guru BK (IPKGBK) pengembangan dinilai layak digunakan untuk menilai kinerja guru BK yang telah melaksanakan program BK komprehensif yang dapat dilihat di dalam lembar penilaian validator praktisi pada model hipotetis.

\section{DAFTAR PUSTAKA}

Gysbers, C.N\& Henderso, Patricia. 2006. Developing \& Managing, Your School Guidance and Counseling Program. Fourth Edition. American Counseling Association, 5999 Stevensonalexanderia

Peraturan Bersama Menteri Pendidikan Nasional dan Kepala Badan Kepegawaian Negara Nomor 03/V/PB/2010 dan Nomor 14 Tahun 2010.

Peraturan Menteri Pendidikan Nasional Nomor 27 Tahun 2008 tentang Standar Kualifikasi Akademik dan Kompetensi Konselor.

Suherman, 2013. Manajemen Bimbingan dan Konseling. Bandung: Rizqi Press

Samsudi. 2009. Desain Penelitian Pendidikan. Semarang: Unnes Press

Sugiyono. 2009. Metode Penelitian Pendidikan: Pendekatan Kuantitatif, Kualitatif dan R\&D. Bandung: Alfabeta. 